\title{
Jumlah Bakteri Coliform Pada Sapi Bali Menurut Tingkat Kedewasaan Dan Lokasi Peternakan Di Nusa Penida
}

\section{(NUMBER OF COLIFORM BACTERIA IN BALI CATTLE BASED ON MATURITY LEVEL AND LOCATION OF FARMS IN NUSA PENIDA)}

\author{
Bianca Violanda Junus ${ }^{1}$, I Nengah Kerta Besung ${ }^{2}$, I Gusti Ketut Suarjana ${ }^{2}$, \\ Ni Ketut Suwiti ${ }^{3}$ \\ ${ }^{1}$ Praktisi Dokter Hewan di Denpasar \\ ${ }^{2}$ Laboratorium Bakteriologi Fakultas Kedokteran Hewan Universitas Udayana \\ ${ }^{3}$ Laboratorium Histologi Veteriner Fakultas Kedokteran Hewan Universitas Udayana \\ Jl. PB Sudirman Denpasar Bali. Email: bianjunus@gmail.com
}

\begin{abstract}
ABSTRAK
Penelitian ini bertujuan untuk mengetahui pengaruh tingkat umur dan lokasi peternakan terhadap jumlah bakteri coliform pada feses sapi bali di Nusa Penida. Sampel yang digunakan berupa feses sapi bali betina dengan total keseluruhan 24 sampel. Penelitian ini menggunakan Rancangan Acak Kelompok (RAK) pola faktorial $2 \times 3$ terdiri atas dua lokasi ketinggian dataran (dataran rendah, dataran tinggi) dan tiga tingkatan umur (pedet, dara, dan dewasa). Sampel ditumbuhkan pada media Nutrient Agar dengan cara metode tuang. Data yang diperoleh diuji dengan analisis ragam yang dilanjutkan dengan Uji Beda Nyata Terkecil (BNT). Hasil analisis ragam menunjukkan jumlah bakteri coliform berbeda nyata pada tingkat kedewasaan dan lokasi peternakan. Jumlah bakteri coliform pada dataran rendah $\left(138,66 \times 10^{7} \mathrm{CFU} / \mathrm{g}\right)$ lebih banyak secara nyata dibandingkan sapi bali yang dipelihara di dataran tinggi $\left(102 \times 10^{7} \mathrm{CFU} / \mathrm{g}\right)$. Hasil Uji BNT menunjukkan jumlah coliform pada sapi pedet sebanyak $43,25 \times 10^{7} \mathrm{CFU} / \mathrm{g}$ yang sangat nyata lebih rendah dibandingkan dengan sapi dara sebanyak $124 \times 10^{7} \mathrm{CFU} / \mathrm{g}$ dan sapi dewasa sebanyak $193,75 \times 10^{7} \mathrm{CFU} / \mathrm{g}$. Jumlah bakteri coliform sapi dara lebih rendah dibandingkan sapi dewasa.
\end{abstract}

Kata kunci: sapi bali; Nusa Penida; jumlah bakteri coliform; feses.

\begin{abstract}
The aims of this study is to determine the effect of maturity level and location of the farms to the number of coliform bacteria in bali cattle feces in Nusa Penida. 24 samples of bali cattle's feces were used in this research. This study used a Randomized Complete Block Design (RCBD) of 2x3 factorial consist of two location of altitude plateu (lowland and highland) and three maturity level (calves, heifers, and adult). The sample was grown on Nutrient Agar using the casting method. The obtained data were tested by analysis of variance followed by Least Significant Difference (LSD) Test. The results showed that the number of coliform bacteria in bali cattle was significantly different at maturity level and location of the farm. Number of coliform bacteria in bali cattle of the lowland was $\left(138.66 \times 10^{7} \mathrm{CFU} / \mathrm{g}\right)$, which is higher than bali cattle on the high land $\left(102 \times 10^{7} \mathrm{CFU} / \mathrm{g}\right)$. Test results of LSD Test showed the number of coliform cattle calf is $43,25 \times 10^{7} \mathrm{CFU} / \mathrm{g}$ is lower compare to heifers $124 \times 10^{7} \mathrm{CFU} / \mathrm{g}$ and adults $193,75 \times 10^{7} \mathrm{CFU} / \mathrm{g}$. The number of coliform bacteria in feces of heifers cattle is lower than the number of coliform bacteria in feces of adult cattle.
\end{abstract}

Keywords: bali cattle; Nusa Penida; number of coliform bacteria; feces.

\section{PENDAHULUAN}

Nusa Penida merupakan suatu kepulauan di Pulau Bali yang ditetapkan sebagai wilayah pembibitan dan sekaligus pemurnian sapi bali. Secara umum kondisi topografi Nusa Penida tergolong landai sampai berbukit sehingga daerahnya dapat dibedakan atas dataran tinggi dan dataran rendah. Desa-desa pesisir sepanjang pantai bagian utara berupa lahan datar dengan kemiringan 0-3\% dari ketinggian lahan 0$268 \mathrm{~m}$ dpl. Semakin ke Selatan kemiringan lerengnya semakin bergelombang (Pemerintah Kab. Klungkung, 2013). Di Nusa Penida tidak ditemukan sungai, sehingga untuk 
mencukupi kebutuhan air masyarakat bergantung pada mata air dan air hujan. Keadaan tersebut menjadi permasalahan utama untuk pengembangan pembibitan, khususnya pemeliharaan sapi bali.

Sapi bali (Bos sondaicus, Bos javanicus, Bos/Bibos banteng) adalah salah satu jenis sapi yang penting bagi perkembangan industri untuk mendukung pariwisata di Bali dan Indonesia umumnya. Hal ini disebabkan sapi bali memiliki potensi yang sangat baik untuk penyediaan daging dan bibit karena mempunyai kemampuan adaptasi yang baik dengan sifat reproduksi berkualitas baik (Suranjaya et al., 2010; Jan et al., 2015).

Tujuh puluh persen dari produktivitas sapi bali, terutama untuk pertumbuhan dan kemampuan produksinya dipengaruhi oleh faktor lingkungan, dan $60 \%$ dari faktor lingkungan tersebut adalah pakan, kandungan nutrien, dan teknologi memformulasikan ransum. Hal ini menunjukkan bahwa kemampuan sapi bali untuk menyerap nutrisi sangat mempengaruhi produktivitasnya (PKSB, 2012).

Kemampuan produktivitas tersebut selain ditentukan oleh faktor di atas, dipengaruhi juga oleh keberadaan mikroorganisme dalam saluran pencernaan. Sapi bali dalam proses pencernaan memerlukan mikroorganisme untuk mencerna serat tanaman dan menghasilkan asam volatil lemak (VFA). VFA mampu memasok 55-60\% dari energi yang dibutuhkan oleh ternak (Pamungkas et al., 2008). Mikroorganisme dalam saluran pencernaan sapi bali terdiri dari jamur, protozoa dan bakteri. Bakteri merupakan mikroorganisme yang paling dominan.

Salah satu kelompok bakteri yang penting dalam saluran cerna sapi bali adalah bakteri coliform. Bakteri coliform termasuk dalam kelompok Enterobacteriaceae yang dapat memfermentasi laktosa. Sebagian besar bakteri coliform adalah flora normal pada sapi bali, akan tetapi bila dalam jumlah besar bakteri coliform akan menimbulkan keadaan patologis. Selain itu pada bakteri coliform terdapat species seperti Escherichia coli yang memiliki galurgalur tertentu yang mampu menyebabkan gastroenteritis taraf sedang sampai parah pada manusia dan hewan (Darmawan et al., 2015). Bakteri coliform yang keluar bersama feses juga mampu menimbulkan pencemaran yang dapat menimbulkan penyakit.

Populasi coliform pada saluran pencernaan sapi tergantung dari jenis sapi, umur dan pakan yang diberikan. Jumlah coliform pada sapi dewasa di Amerika yang diberikan jagung sebanyak 30.103 CFU/g (Sindt et al., 2002). Diez-Gonzalez et al. (1998) melaporkan jumlah coliform pada feses sapi dewasa di Meksiko sebanyak $838.849 \quad \mathrm{CFU} / \mathrm{g}$. Namun populasi coliform pada sapi bali pedet, dara dan dewasa di Nusa Penida belum pernah dilaporkan. Maka dari itu penelitian ini bertujuan untuk mengetahui perbedaan jumlah bakteri coliform antar tingkatan umur dan lokasi pemeliharaan.

\section{METODE PENELITIAN}

\section{Materi}

Objek penelitian ini adalah feses bibit sapi bali betina yang diambil dari Nusa Penida, yang berasal dari sapi pedet, dara dan dewasa. Sample feses sapi tersebut diambil dari dua lokasi yaitu dataran tinggi (Desa Sekartaji) dan dataran rendah (Desa Kutampi Kaler). Semua sampel berasal dari sapi betina. Setiap kombinasi perlakuan dilakukan pengulangan 4 kali, sehingga jumlah sapi yang digunakan adalah 24 ekor.

\section{Metode}

Sampel berupa feses diambil dengan cara melakukan palpasi rektal. Sampel kemudian disimpan di dalam tabung lalu dimasukan ke dalam boks sebelum dibawa ke laboratorium. Sebelum melakukan penanaman, dilakukan pengenceran sampel sampai $10^{-7}$. 
Penanaman bakteri menggunakan metode sebar. Dari hasil pengenceran (suspensi $10^{-7}$ ) diambil $0,1 \mathrm{ml}$ suspensi bakteri kemudian diteteskan ke dalam media menggunakan mikropipet. Suspensi tersebut disebar ke seluruh permukaan media menggunakan batang gelas bengkok yang telah disterilkan. Setelah ditanami bakteri, media kemudian dimasukan ke dalam inkubator dengan suhu $37^{\circ} \mathrm{C}$ selama 12 jam. Koloni bakteri yang diamati adalah koloni coliform yang berwarna hijau gelap sampai hijau metalik.

\section{Analisis Data}

Menurut Fardiaz (1992), untuk mendapatkan jumlah koloni per gram feses dipakai rumus:

\section{Jumlah koloni \\ pengenceran $X$ inokulum $\mathrm{CFU} / \mathrm{gr}$}

Sumber: (Zuanita et al, 2014)

Data bakteri coliform berdasarkan tingkatan umur dan lokasi peternakan diolah menggunakan Rancangan Acak Kelompok (RAK) pola faktorial, yang dianalisis dengan analisis varian (ANOVA) yang sebelumnya data ditransformasi ke dalam log Y. Jika perlakuan menunjukkan perbedaan yang nyata dilanjutkan dengan uji Beda Nyata Terkecil (BNT) (Sampurna dan Nindhia, 2008).

\section{HASIL DAN PEMBAHASAN}

\section{Hasil}

Berdasarkan hasil penelitian yang dilakukan pada 24 sampel feses sapi bali yang diambil berdasarkan tingkat kedewasaan dan lokasi peternakan didapatkan jumlah bakteri coliform pada feses sapi bali pada tabel 1 .

Hasil analisis ragam menunjukkan kelompok tidak berpengaruh nyata $(\mathrm{P}>0,05)$ terhadap jumlah bakteri coliform. Semua ulangan yang dipakai dalam penelitian bersifat seragam. Antara ulangan pertama, kedua, ketiga dan keempat tidak menunjukkan perbedaan yang nyata. Lokasi peternakan berbeda nyata $(\mathrm{P}<0,05)$ terhadap jumlah bakteri coliform. Jumlah bakteri coliform pada Sapi yang dipelihara di lokasi peternakan dataran rendah sangat nyata lebih banyak dibandingkan dengan sapi yang dipelihara di dataran tinggi $(102 \pm 75,78 \mathrm{CFU} / \mathrm{g})$. Hal ini disebabkan oleh suhu dataran. Dalam hal ini suhu desa Kutampi yang merupakan dataran rendah $\left(23,8-34,0^{\circ} \mathrm{C}\right)$ lebih mendekati suhu optimum perkembangan bakteri coliform $\left(37^{\circ} \mathrm{C}\right)$ (Nguyen, 2006) dibandingkan suhu desa Sekartaji yang merupakan dataran tinggi $\left(20,0-31,0^{\circ} \mathrm{C}\right)$. Ketersediaan air di dataran rendah Nusa Penida lebih tinggi dibandingkan dengan dataran tinggi. Ketersediaan air di dataran rendah ini akan berdampak pada suburnya tanah. Selain itu, akibat pengaruh erosi tanah di dataran rendah lebih subur dibandingkan dengan dataran tinggi (Susilawati et al., 2013). Pada saat hujan unsur hara yang ada di dataran tinggi akan hanyut ke dataran yang lebih rendah, sehingga unsur hara di dataran tinggi akan berkurang. Faktorfaktor tersebut akan berdampak pada kesuburan tanaman. Sehingga tanaman yang tumbuh pada dataran rendah memiliki lebih banyak kadungan dan variasi nutrisi.

\section{Pembahasan}

Sapi yang dipelihara di dataran rendah akan mendapat asupan pakan yang memiliki variasi kandungan nutrisi lebih bayak dibandingkan dengan yang dipelihara di dataran tinggi. Kandungan yang ada pada pakan akan berdampak pada kandungan flora normal yang ada di dalam saluran pencernaan. Selain itu, air yang mengalir dari dataran tinggi ke rendah juga dapat menyebabkan bakteri coliform dari dataran tinggi terbawa hingga ke dataran rendah. Cara pemeliharaan masyarakat juga memiliki potensi menjadi penyebab kontaminasi pada dataran rendah lebih tinggi karena masyarakat dataran rendah khususnya desa Kutampi cenderung mengandangkan sapinya namun sanitasi kandangnya masih tergolong buruk sehingga meningkatkan 
kemungkinan kontaminasi. Berbeda dengan masyarakat di dataran tinggi karena mereka cenderung melepas sapinya sehingga kemungkinan pakan dan minum sapi terkontaminasi menjadi kecil.

Hasil analisis uji BNT menunjukkan bahwa jumlah coliform sapi pedet lebih sedikit $(\mathrm{P}<0,01)$ dibandingkan sapi dara dan sapi dewasa. Pada sapi dara jumlah coliform lebih sedikit dibandingkan sapi dewasa. Data tersebut menunjukkan bahwa semakin dewasa sapi tersebut semakin banyak jumlah bakteri coliform di dalam fesesnya.

Tabel 1. Rata-rata Jumlah Bakteri Coliform Feses Sapi Bali Menurut Tingkat Kedewasaan dan Lokasi Peternakan

\begin{tabular}{ccccccc}
\hline \multirow{3}{*}{ Ulangan } & \multicolumn{6}{c}{ Lokasi Peternakan $\left(10^{7} \mathrm{CFU} / \mathrm{g}\right)$} \\
\cline { 2 - 7 } & \multicolumn{3}{c}{ Dataran Tinggi } & \multicolumn{3}{c}{ Dataran Rendah } \\
\cline { 2 - 7 } & Pedet & Dara & Dewasa & Pedet & Dara & Dewasa \\
\hline 1 & 11 & 135 & 210 & 46 & 92 & 220 \\
2 & 11 & 63 & 108 & 114 & 168 & 198 \\
3 & 25 & 116 & 150 & 53 & 134 & 200 \\
4 & 35 & 120 & 240 & 51 & 164 & 224 \\
\hline Rataan & 20,5 & 108,5 & 177 & 66 & 139,5 & 210,5 \\
\pm SD & 11,71 & 31,42 & 59,29 & 32,14 & 35,11 & 13,4
\end{tabular}

Pada sapi pedet, pakan utama yang dikonsumsi berupa susu yang berasal dari induknya. Susu tersebut akan di olah di retikulum dan diabsorpsi di usus halus, Kandungan karbohidrat, protein dan lemak akan di absorpsi di usus halus, sehingga yang diteruskan ke usus besar jumlahnya terbatas. Selain itu, susu tersebut mengandung kolostrum dimana mikroba dalam kolostrum, dan senyawa dalam kolostrum dapat menghasilkan antimikroba yang menghambat pertumbuhan bakteri gram positif maupun gram negatif (Khotima et al., 2013). Pada sapi dara, sudah memulai belajar makan daun-daunan dan rumput. Pada tingkat kedewasaan ini, proses fermentasi sudah terjadi di dalam rumen.

Hasil fermentasi akan diserap di dalam usus halus. Namun serat kasar akan diteruskan ke usus besar untuk proses pencernaan secara bakteriologis. Proses yang hampir sama juga terjadi pada sapi dewasa. Pada sapi dewasa, rumen sudah berfungsi sempurna, dan pencernaan pakan secara enzymatis terjadi di dalam rumen dan pencernaan bakteriologis terjadi di usus besar. Dengan demikian kandungan karbohidrat, protein, lemak dan mineral di dalam usus besar sangat banyak.

Tingginya kandungan karbohidrat, lemak, protein, dan mineral di dalam usus besar akan memicu perkembangan bakteri yang ada di saluran pencernaan tersebut. Selain itu, kemungkinan kontaminasi bakteri coliform terjadi pada pakan hijauan lebih tinggi dibandingkan ASI yang dikonsumsi pedet.

\section{SIMPULAN DAN SARAN}

\section{Simpulan}

Berdasarkan hasil penelitian yang dilakukan, dapat disimpulkan jumlah bakteri coliform sapi bali mengalami peningkatan seiring dengan kenaikan kedewasaan umur sapi dan jumlah bakteri coliform pada sapi yang dipelihara di dataran rendah $(138,67 \pm 66,81 \quad \mathrm{CFU} / \mathrm{g})$ lebih tinggi dibandingkan dengan sapi yang dipelihara di dataran tinggi $(102 \pm 75,78 \mathrm{CFU} / \mathrm{g})$.

\section{Saran}

Perlu dilakukan penelitian lebih lanjut yang lebih spesifik mengenai identifikasi jenis bakteri coliform yang terdapat dalam feses sapi bali di Nusa Penida. 


\section{UCAPAN TERIMAKASIH}

Melalui kesempatan ini penulis ingin mengucapkan terimakasih kepada Rektor Universitas Udayana atas pendanaan dari Hibah Invensi Universitas Udayana tahun 2015. Ucapan terimakasih juga ditujukan kepada semua pihak yang telah membantu dalam penelitian ini sehingga dapat terselesaikan dengan baik.

\section{DAFTAR PUSTAKA}

Darmawan Y, Swacita IBN, Suardana IWS. 2015. Perbandingan Bakteri coliform, E. coli, E. coli O157, dan E. coli O157:H7 pada Sapi bali di Mengwi, Badung, Bali. Indon. Med. Vet. 4: 362-373.

Diez-Gonzalez F, Callaway TR, Kizoulis MG, Russell JB. 1998. Grain feeding and the dissemination of acidresistant Escherichia coli from cattle. Science. 281: 1666-1668.

Jan R, Sudrana IP, Kasip LM. 2015. Pengamatan Sifat-sifat yang Mempunyai Nilai Ekonomi Tinggi pada Sapi Bali di Kota Mataram. J. Ilmu dan Teknologi Peternakan Indon. 1(1): $53-59$.

Khotimah K, Fahrizal. 2013. Kualitas Mikrobiologi Kolostrum Sapi Perah FH pada Waktu Pemerahan yang Berbeda di Peternakan Rakyat. J. Ilmu Ternak. 13(2): 13-17.

Nguyen, MT. 2006. The effect of temperature on the growth of the bacteria Escherichia coli DH5a. Saint Martin's University Biol. J. 1: 88-94.

Pamungkas D, Anggraeni YN, Kusmartono, Krishna NH. 2008.
Produksi Asam Lemak Terbang dan Amonia Rumen Sapi Bali pada Imbangan Daun Lamtoro (L. leucocephala) dan Pakan Lengkap yang Berbeda. Prosiding. Seminar Nasional Teknologi Peternakan dan Veteriner. Pp: 197-204.

Pemerintah Kabupaten Klungkung. 2013. Rencana Pembangunan Jangka Menengah Daerah (RPJMD) Kabupaten Klungkung Tahun 20132018. Semarapura, Klungkung.

Pusat Kajian Sapi Bali Universitas Udayana. 2012. Sapi Bali: Sumber Daya Genetik Asli Indonesia. Udayana University Press. Bali.

Sindt JJ, Drouillard JS, Thippareddi H, Phebus RK, Coetzer CM, Kerr KD, Lambert DL, Farran TB, Montgomery SP, LaBrune HJ. 2003. Effect of Maillard reaction products on ruminal and fecal acid-resistant $E$. coli, total Coliforms, VFA profiles, and $\mathrm{pH}$ in steers. J. Anim. Sci. 82(4): 11701176.

Suranjaya IG, Ardika IN, Indrawati RR. 2010. Faktor-Faktor yang Mempengaruhi Produktivitas Sapi Bali di Wilayah Binaan Proyek Pembibitan dan Pengembangan Sapi Bali di Bali. Majalah Ilmiah Peternakan. 13(3): 8387.

Susilawati, Mustoyo, Budhisurya E, Anggono RCW, Simanjuntak BH. 2013. Analisis Kesuburan Tanah dengan Indikator Mikroorganisme Tanah pada Berbagai Sistem Penggunaan Lahan. Agric. 25(1): 6472. 